\title{
A Circum-Pannonian Word-Prosodic Parallel: Paroxytonic Accent in the South-West Bohemian Dialect
}

\author{
Zbyněk Holub-Marc L. Greenberg
}

Cobiss: 1.01

\begin{abstract}
Obpanonska prozodijska vzporednica na besedni ravni: paroksitoneza $\mathrm{v}$ jugozahodnem češkem narečju
\end{abstract}

Slavisti imajo češko-slovaška narečja v glavnem za področje, kjer prevladujejo konfiguracija ustaljenega iktusa (naglasa) v prvem besednem zlogu in nasprotja po kolikosti v katerem koli besednem zlogu. Znana izjema je šlezijsko narečje, ki ima podobno kot poljščina ustaljeni naglas na predzadnjem zlogu. Manj znano pa je stanje v jugozahodnem češkem narečju (Plzen, Češke Budjejovice); to izkazuje »paroksitonični naglas«, ki je na prvi pogled podoben šlezijski konfiguraciji.

Ključne besede: besedna prozodija, češka narečje, slovenska narečja, tonemskost, praslovanska narečja

Slavists generally think of the Czecho-Slovak dialect area as having a wordprosody configuration of fixed word-initial stress with contrastive length possible in any syllable. A notable exception is the Silesian dialect area, which typically has the Polish configuration with fixed penultimate stress and no contrastive length. Much less familiar is a small area in SW Bohemia (Pilsen, České Budějovice and environs) with what has been termed "paroxytonic stress" and contrastive length, which at first blush may be considered akin to the Silesian configuration.

Keywords: word prosody, Bohemian dialects, Slovene dialects, pitch-accent systems, Proto-Slavic dialects

\section{Introduction}

The south-western subgroup of the Czech inter-dialect (SWC; in the narrow sense of Czech as "Bohemian," in contrast to Moravian and Silesian) displays a number of phonological features that differentiate it from obecná čeština (OČ) in such a way as to mark them with opposite values to the "expected" ones. ${ }^{1}$ In the following we

1 The authors have presented earlier versions of this work-in-progress at two meetings, the first being the Seventh Meeting of the Slavic Linguistics Society, August 2012, Lawrence, Kansas, USA and the second the Slovenski dialektološki posvet 2, ZRC SAZU, Ljubljana, November 2012. The authors are grateful to audience members at each of these meetings for fruitful discussion and the comments offered at each have been taken into account in 
$\hookrightarrow \quad$ will make note of two subsets of SWC, marked provisionally with the letters $\mathrm{P}, \mathrm{D}$,

[I] where $\mathrm{P}=$ the "Pilsen group" (W) and D = the "Doudleby group." 2 These localities

N are represented in Figure 1.

Figure 1. Areal of the phenomenon with southwestern Bohemian areas mentioned in the text. The two clusters are provisionally labeled: $\mathbf{P}=$ the Pilsen group $(\mathrm{W})$ and $\mathbf{D}=$ the Doudleby group (S)

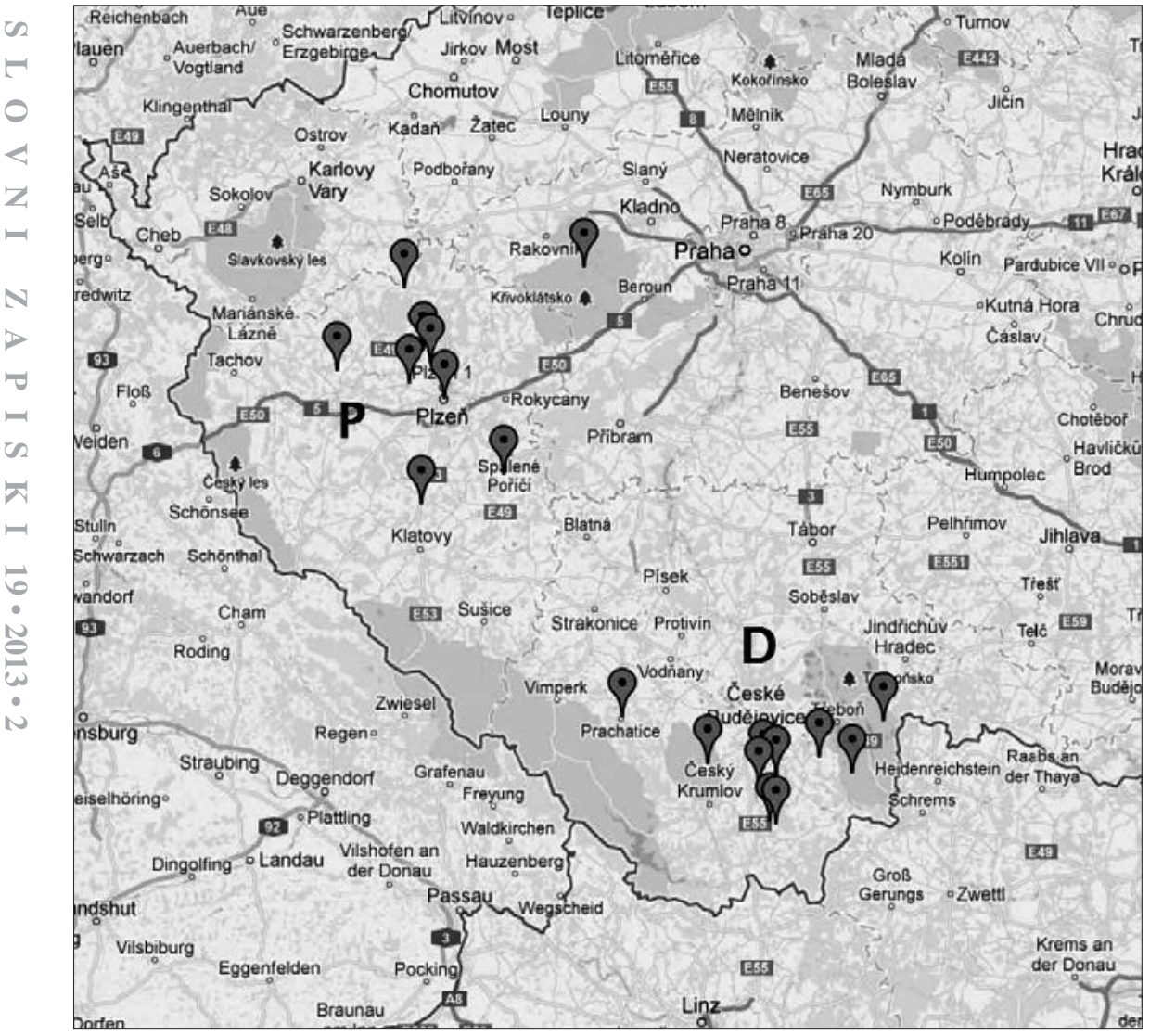

To note just a few peculiarities of the SWC type (including P, D), concerning matters of word- and, possibly, sentence-prosody, we adduce the following:

reworking this paper for publication. The division of labor in the paper is as follows: the fieldwork, grounding of the problem in the Czech dialectological literature, and questions raised about the nature and origin of the Pilsen/Doudleby-type prosodic peculiarities are the contribution of Zbyněk Holub; acoustic analyses of the material, using PRAAT phonetic-analysis software, and the attempt to explain the peculiarities and their origin are the contribution of Marc L. Greenberg.

2 Doudleby is used as the emblematic point of reference for the group following the tradition in the relevant Czech dialectological literature; moreover, it is less cumbersome than referring repeatedly to "the environs of České Budějovice." 
A. Disyllabic AP “a”3 nouns of the type *plèva 'husk', *ry"ba 'fish' are reflected as long plíva, rejba vs. StCz pleva, ryba (Bělič 1972: 133, map 21; Balhar and Jančák 2006: 185; Holub 2011a: 7).

B. Monosyllabic AP “a” nouns of the type *čäsъ 'time' are often reflected as long, e.g., čás vs. StCzčas, including also the "metatonic" type in the geen. pl. *krävz 'of cows': kráv vs. StCz krav (Bělič 1972: 133, map 21).

C. Monosyllabic AP "c" nouns of the type *snégz 'snow' are often reflected as short sněh vs. StCz sníh (Bělič 1972: 133, map 21).

D. In D and partially in $\mathrm{P}$ a secondary stress - the primary stress being, as in standard Czech in the first syllable - with a phonetic rising contour occurs in penultimate syllables, e.g., u řež̌ika kramářka, že diby něco začal, že dostane tuplováňe (Doudleby), where the rising contour is indicated by boldface type (Havránek 1934: 116).

E. In the literature $\mathrm{P}$ a word-level intonation with a rising pitch contour, "The Pilsen melody," (plzeňské zpívání) occurs in both declarative and interrogative sentences in the focus position (usually the final part of an utterance) in the penultimate syllable. The characteristic rising sentence cadence, which not found in OČ cadences, is illustrated in the schematic diagram by Voráč in Figure 2 (Voráč 1955: 70; see also Petřík 1936a, 1936b).

Figure 2. "The Pilsen melody" (plzeňské zpíváni), adapted from Voráč (1955: 70)

a. Sulislav, wife of a farmer ("žena rolnika"), age 84

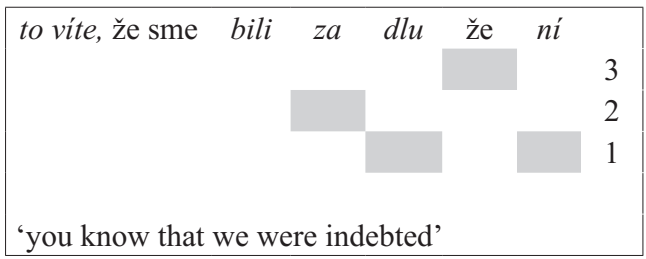

\begin{tabular}{|l|r|}
\hline nevjestu vy ku po va li & \\
& 4 \\
& 3 \\
& 2 \\
& 1 \\
& \\
'they ransomed the bride' & \\
\hline
\end{tabular}

b. Manětín area (L: Manětín, female tenant farmer, 86; R: Hvozd, female tenant farmer, 62)

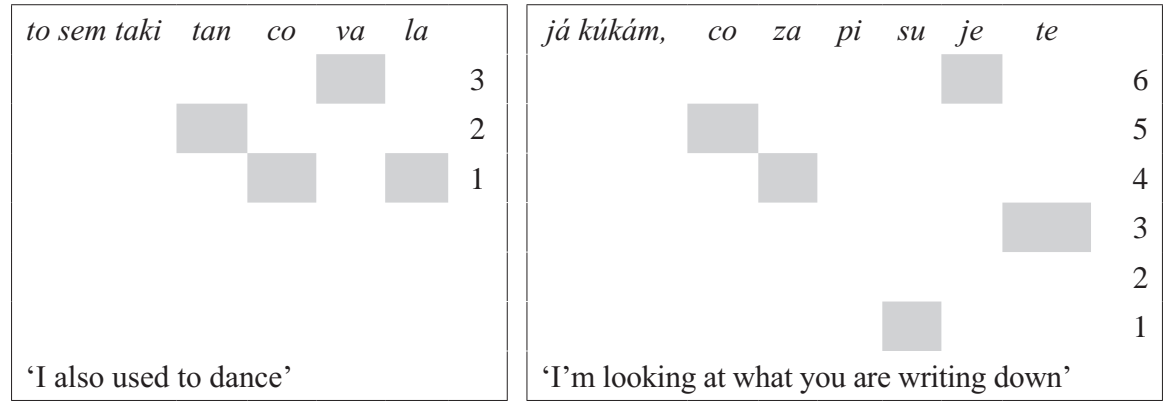

3 Here Christian Stang's well-known typology of the Proto-Slavic accentual paradigms is used as a point of departure with the following notation: AP = accentual paradigm; 
Voráć's stylization of the prosodic phenomenon, obviously conveying his perception, suggests the following: that the typical focus position (sentence/utterance-final position) is characterized by a cadence in which the penultimate syllable carries the pitch peak. In a four-syllable word (Vite, že sme bili zadlužení; To sem taki tancov$\underline{a l a}$ ). Vorác requires three pitch levels to describe the countour, whereby the pitch of the first syllable of the last (focused) word begins in the middle of the range, drops to the low range in the second syllable, rises to the peak in the third (penultimate) and then drops to the low range in the final syllable. In five- (Nevjestu vikupovali) and six-syllable (Já kúkám, co zapisujete) focused words he requires four and six pitch levels, respectively. The commonality between the shorter longer words is that the antepenultimate syllable drops to the lowest pitch level in the schema, immediately followed by the penultimate syllable reaching the pitch peak; the pattern is better articulated in the longer words, whereby the pre-antepenultimate syllable manifests an additional level of pitch drop before reaching the lowest level in the antepenultima.

In the more southerly localities around Doudleby, the phenomenon is found more consistently at the word level in some $70-80 \%$ of bisyllabic words (Holub 2011a). We thus now turn to some examples from Holub's material and examine it using instrumental measurement that strike us as typical of the pattern. In Figures $3 \mathrm{a}$ and $3 \mathrm{~b}$ we can observe the pitch contour as exemplified by two female speakers born in 1927 from the villages Smrhov (S of České Budějovice) and Borovany (SE of $\check{C} B$ ). In figure $3 \mathrm{a}$ is an example of the pattern found in utterance medial (nonfocus) position. Measurements were taken at key points in the utterance and are given in the table below the figure. They indicate a relative longer penultimate syllable $/ \mathrm{ka} /$, /dě/, even if the inherent vowel is phonemically short (as they are in this example). In both cases the penultimate syllable is lower in pitch than in the final syllable of each word. $/ \mathrm{ka}$ / shows a slight rising trend, though the overall effect is of a lower tone, following the slight rise in the previous syllable $/ \mathrm{na} /$. The penultimate syllable in the second word /dě/ has a falling-rising contour preceded by a lower pitch in the preceding syllable /ne/.

Figure $3 \mathrm{~b}$ shows a trisyllabic word (vodovod) in focus position (end of the utterance) with the pattern showing the characteristics of the D-type contour. In this example, the pitch contour is indicated by the dotted line (blue in the original). In this example the penultimate and ultimate syllables are approximately equal, the final syllable typically being somewhat lengthened in utterance-final position. The antepenultimate syllable is slightly falling and lower than the penultimate syllable, which outlines a fairly steep rise, followed by a falling pitch in the ultimate syllable.

AP "a" = stem-stressed with "old-acute" stress type throughout the paradigm; AP "b" = desinence-stressed alternating with "neo-acute" on the pre-desinential syllable; AP "c" = mobile stressed, alternating between recessive "circumflex" (falling) stress on the stem and marginal end stress on the desinence. 
Figure 3a. Example of rising pitch contour [na každou neděli]. Smrhov (S of České Budějovice), female b. 1927

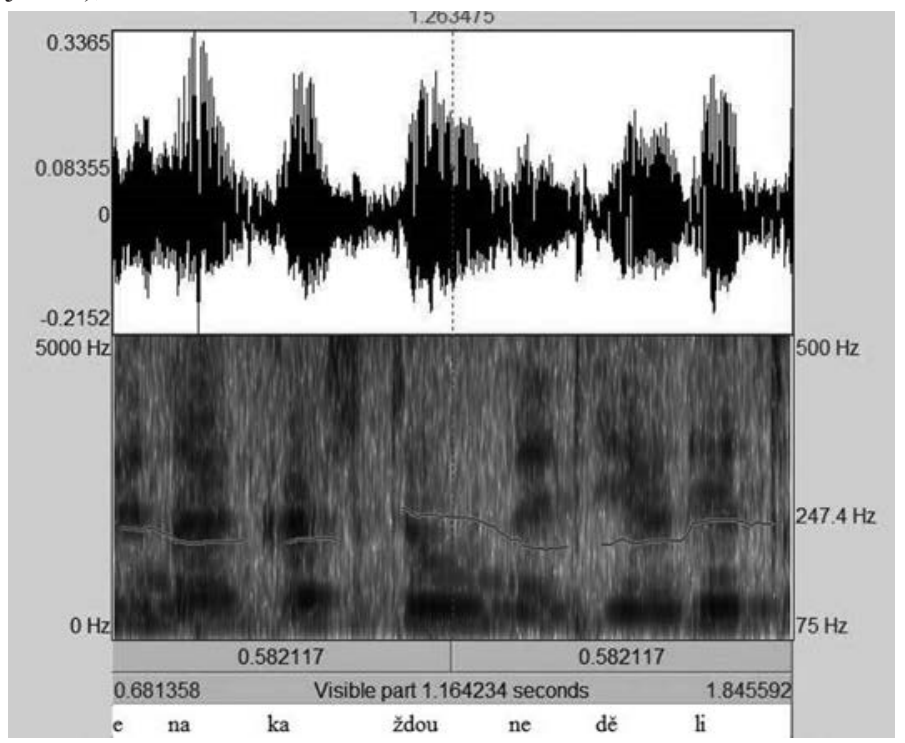

\begin{tabular}{|c|c|c|c|c|c|c|c|c|c|c|}
\hline & \multirow[t]{2}{*}{ na } & \multicolumn{2}{|c|}{ ka } & \multicolumn{2}{|c|}{ ždou } & \multirow[t]{2}{*}{ ne } & \multicolumn{3}{|c|}{ dě } & \multirow[t]{2}{*}{ li } \\
\hline & & beg & end & beg. & end & & beg. & mid. & end & \\
\hline $\begin{array}{l}\text { duration } \\
(\mathrm{sec})\end{array}$ & .10 & & 2 & .13 & & .10 & & .13 & & .09 \\
\hline pitch $(\mathrm{Hz})$ & 215.8 & 213. & 215.4 & 257.3 & 243.6 & 203.0 & 214.6 & 211.4 & 214.7 & 214.7 \\
\hline
\end{tabular}

Figure 3b. Example of rising pitch contour [vodovod] 'water line' in utterance-final position. Borovany (SE of České Budějovice), female b. 1927

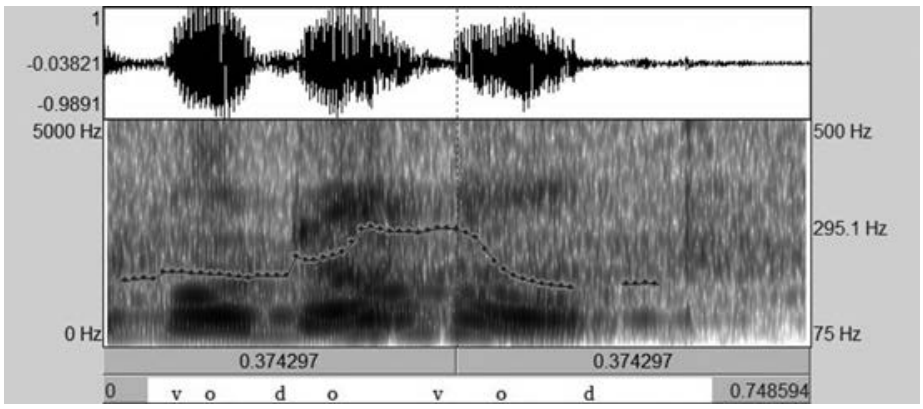

\begin{tabular}{|c|c|c|c|c|c|c|c|}
\hline \multicolumn{3}{|c|}{ vo } & \multicolumn{2}{|r|}{ do } & \multicolumn{3}{|c|}{ vod } \\
\hline & beg. & end & beg. & mid & end & beg. & end \\
\hline $\begin{array}{l}\text { duration } \\
(\mathrm{sec})\end{array}$ & $.0 S$ & & & .14 & & & \\
\hline pitch $(\mathrm{Hz})$ & 213.0 & 205.1 & 237.9 & 257.2 & 294.3 & 290.2 & 188.7 \\
\hline
\end{tabular}


In Figure 4 we notice the same phenomenon in two consecutive polysyllabic words, where the last one is in focus position [lampičkama] and shows clearly the same four characteristics as in Figure 2, though in this case the pitch peak is reached at the beginning of the penultimate syllable (ca. $250 \mathrm{~Hz}$ ) and rises in the preceding, antepenultimate syllable (ca. 175-250 Hz). The preceding word [svit'ily] shows a more subtle variation, but again displays all four characteristics, including the pitch rise and fall (ca. 225-250-210 Hz).

Figure 4. Example of rising pitch contour [tag že sme svít'ili lampičkama] 'so we lit our way with (kerosene) lamps'. Borovany (SE of České Budějovice; D type), female b. 1927

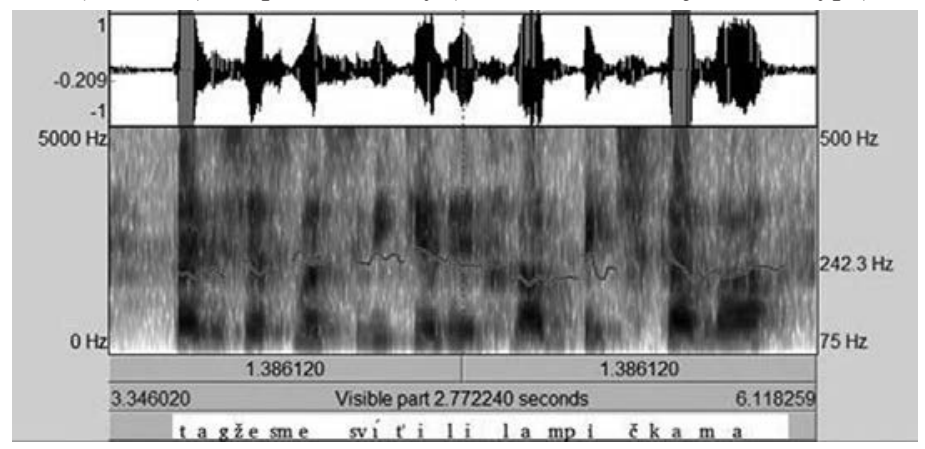

Figure 5 shows a pitch pattern in a larger context. Although it is more of a challenge to view the pitch contours, this utterance gives a better sense of the frequency of the pitch rise at the word level, since none of the words are in focus position. The stretch of text under examination describes a habit of baking a special sort of Sunday bread: "So in this way every Sunday, one would always just bake a loaf of bread, a nice one, this was done from the better flour, from the 'vejražka' as it was called) [...]." In this utterance the boldface syllables reflect the instances where the D type rising pitch occurs. These boldfaced syllables match with the lower and longer pitch

Figure 5. Example of pitch patterns in context. Smrhov (D type), female, b. 1927

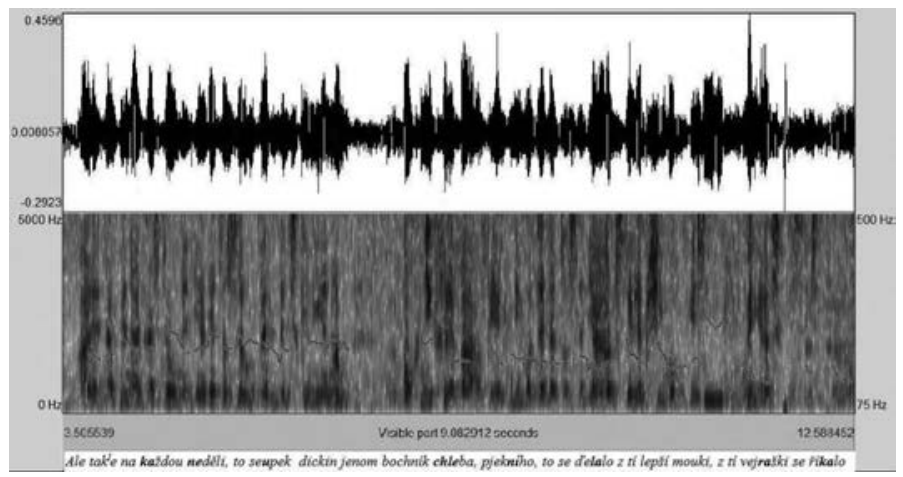


troughs in the contour analysis in the lower half of the diagram, each of which is followed by a higher pitch in the final syllable of the same phonological word. Of note is that the clitic string to se upek 'it was baked' (this[neut.sg] [reflexive particle] bake-[l-participle.masc.sg.]) comprising a single word-like unit. Moreover, this contour is somewhat closer to Voráč's schema in that it describes a lowering of tone before the rise, though in these instances it is the longer, penultimate syllable that is marked by the pitch trough.

To sum up the observations of both perception and measurement of the phenomenon thus far:

- amplitude is highest on the first ("stressed") syllable

- pitch is usually lower and rises in the penultimate syllable

- duration is greatest in the penultimate syllable

- $\quad$ itch either remains high or falls slightly in the final syllable

For two, three- or four-syllable words in SWC, carrying the P, D pitch movement, we can schematize the pattern as follows:

\begin{tabular}{|l|l|}
\hline Two syllables & *HL.H \\
\hline Three syllables & *HL.LH.H \\
\hline Four syllables & *H.L.LH.H \\
\hline
\end{tabular}

\section{Towards an explanation}

In the existing literature there has hardly been any agreement about the explanation for these phenomena-not even whether they are archaic or innovative features, nor whether the appearance of the feature is a function of sentence intonation, word intonation, or whether it is functional (i.e., meaning-differentiating), until relatively recently, thanks to the work of Holub, who has demonstrated that the pattern is non-phonemic, but it is characteristic of word, rather than sentence prosody (Holub 2011a, 2011c, 2011b). Remaining to be explained is the source of this pattern. In this presentation we shall build on Holub's observations and construct a framework to understand where the phenomenon fits into the picture typologically and, in a broader Slavic framework, diachronically.

The geography of this pattern is particularly striking. As is generally known, the "old acute" pitch-accent type in Czech is generally preserved as a long stress, as is evident from composite Map 134 of the ČJA, which shows that the western Bohemian dialects more consistently reflect length in disyllabic words of the type žába'toad', jáma' pit', hrábě 'rake (farm implement)' (see Figure 6). The pattern is the same for verbs with old-acute stress. 
$\hookrightarrow \quad$ Figure 6. Reflexes of old-acute stressed words in Czech (Balhar and Jančák 2006, repro-

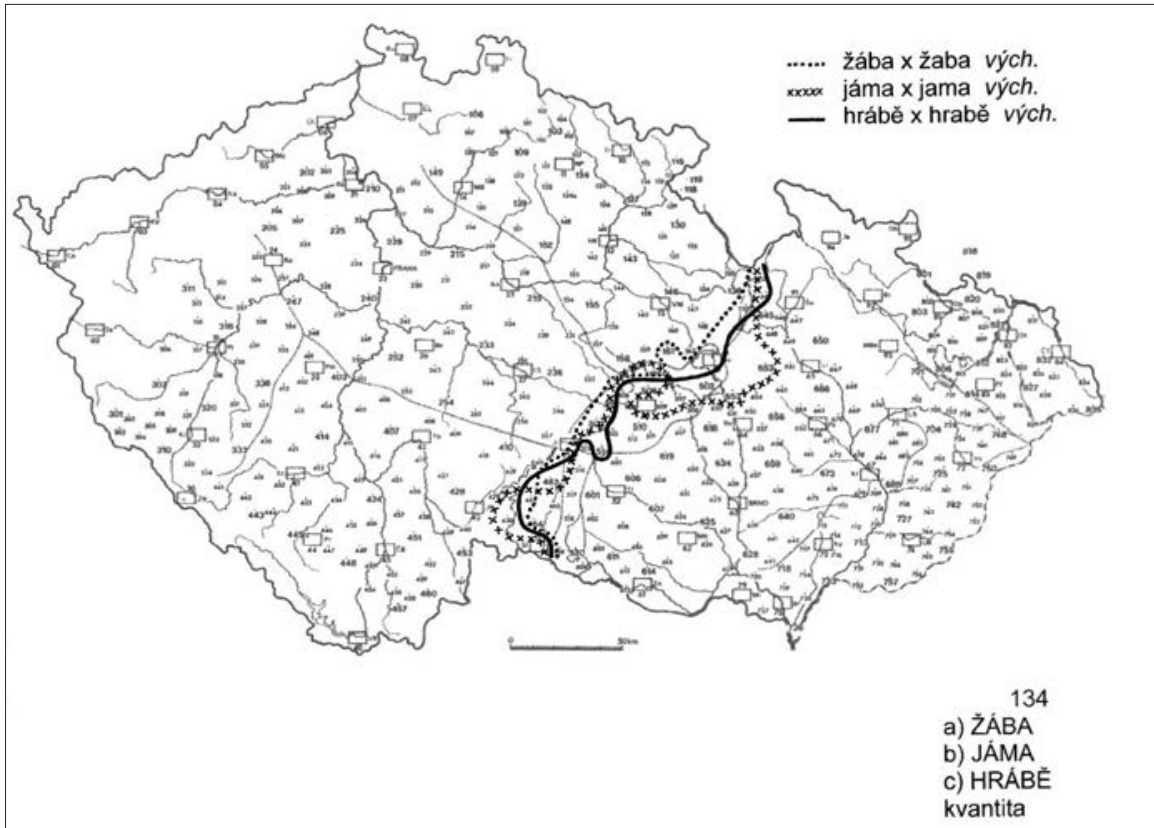

Figure 7. AP "a" monosyllables kraj 'edge', pluh 'plow' with anomalous length in SW Bohemia (Balhar and Jančák 2006, reproduced by permission)

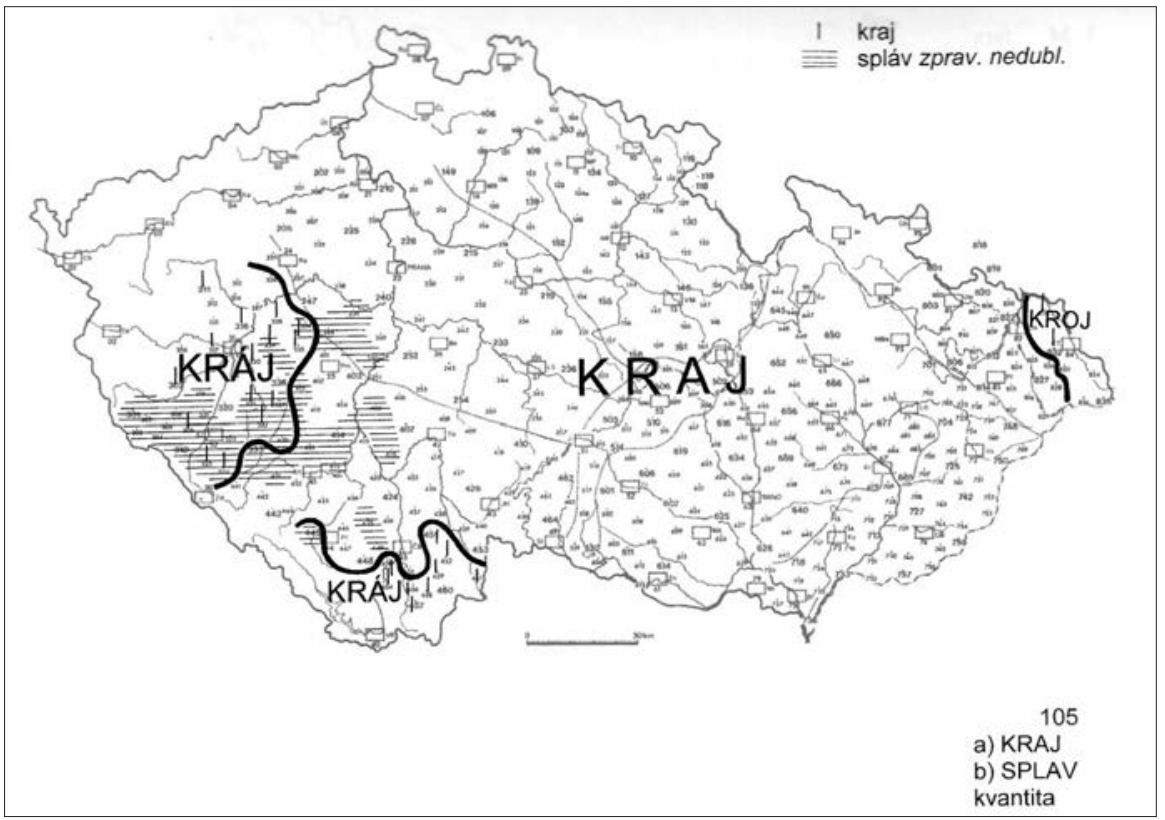




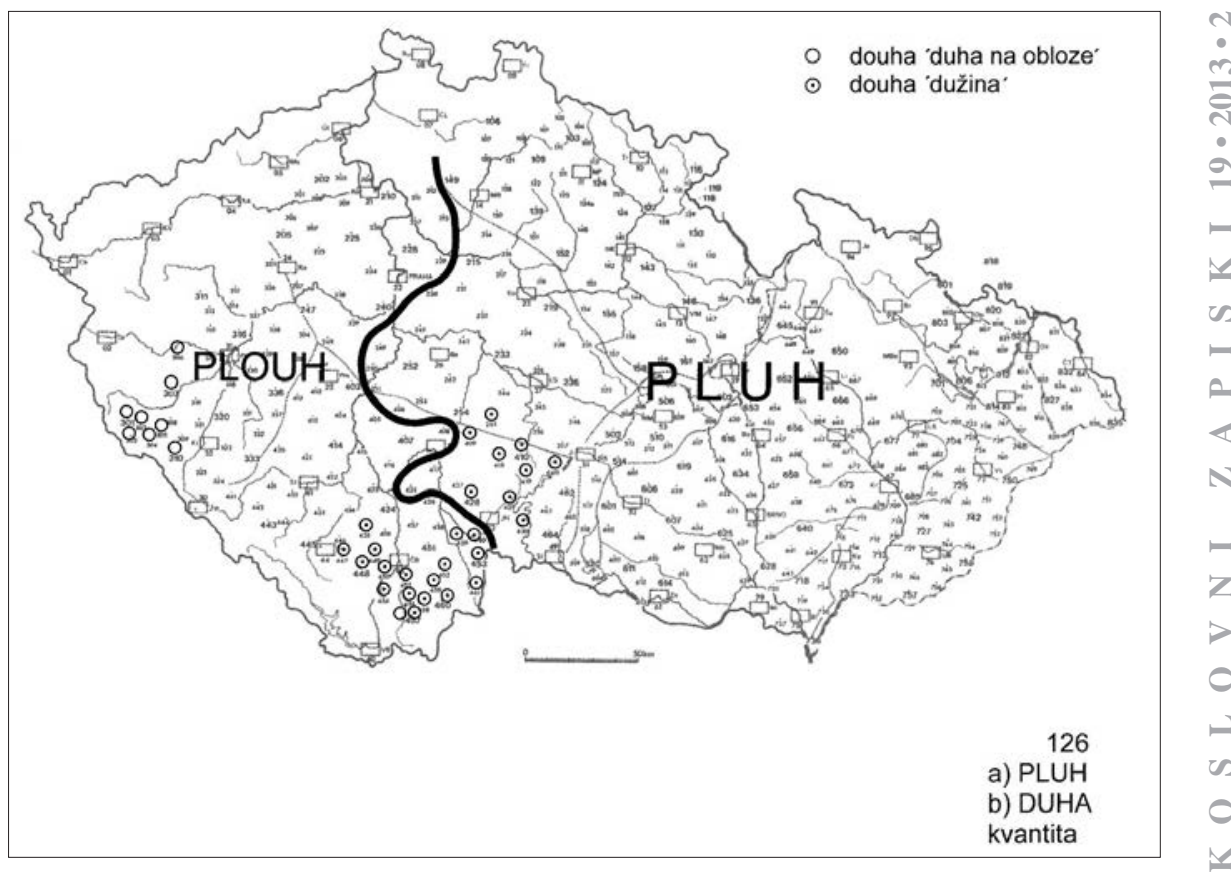

Figure 8. Old-acute reflex pattern for rejba (<rýba) vs. ryba'fish', tchyně 'mother-in-law'. Length in SW Bohemia (Balhar and Jančák 2006, reproduced by permission)

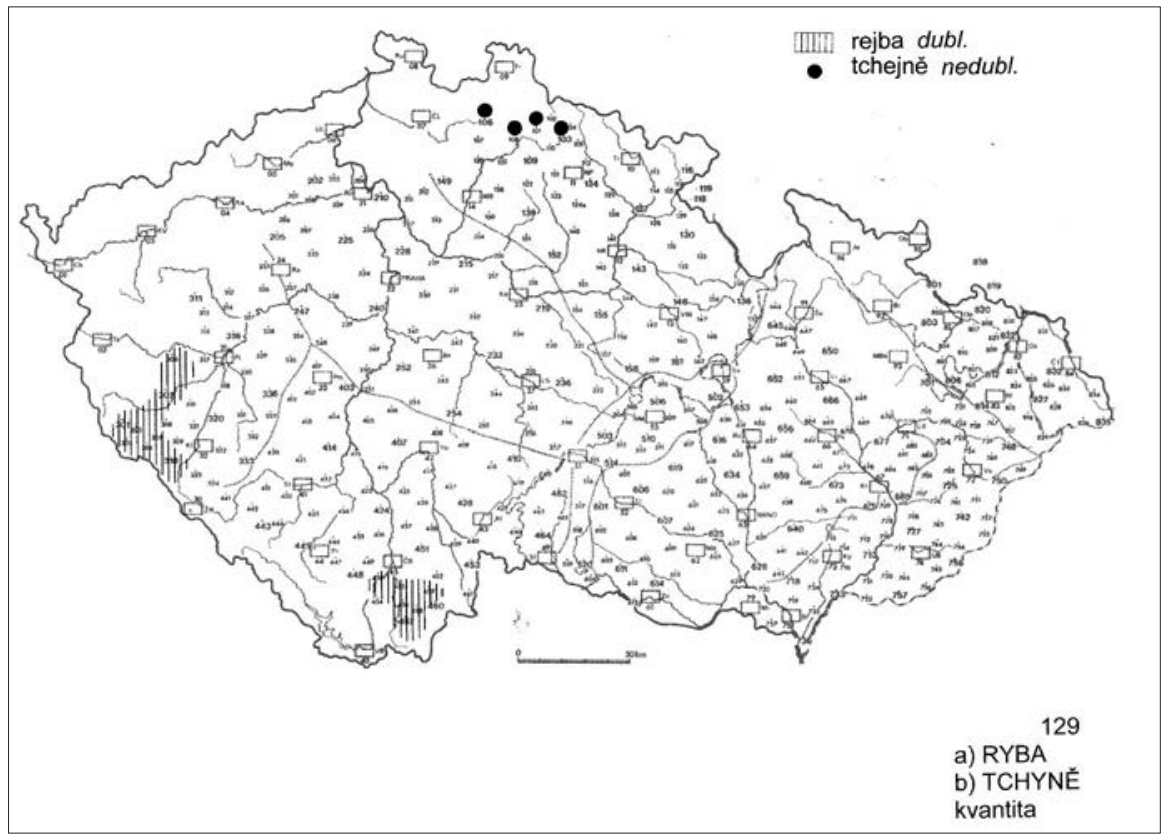


The following sketch is an attempt to explain how the Pilsen/Doudleby prosodic peculiarity arose. The investigation proceeds from the assumption that a pitch phenomenon is more easily explained as a retention rather than an innovation, though it is acknowledged that finding a pitch relic in an the Czecho-Slovak dialect complex is surprising, given that it is invariably treated as a system that has long since converted the Common Slavic pitch-accent system to one with fixed (phonetic) stress marking accentogenic words and contrastive length. For this reason we shall first examine the development of fixed-stress systems. The most comprehensive work on the origins of fixed stress in Slavic remains Baerman's The Evolution of Fixed Stress in Slavic (Baerman 1999). Let us first address some of his methodological principles. In this work he notes that we cannot directly observe the stage of transition between the complex pitch-accent system reconstructed for Common Slavic (and preserved in modified forms in Western South Slavic dialects) and the fixed-stress systems we observe in modern Slavic languages. He focuses on areas of transition in dialect systems corresponding to standard languages, which show transition between the inherited systems and the innovative fixed-stress systems. For this reason Baerman concentrates on three case studies: (a) Macedonian, where the standard language and much of the dialect area has fixed antepenultimate stress, but penultimate and initial stress are also attested; the eastern dialects of Macedonian, transitioning to Bulgarian, have free stress. (b) Kashubian, which has fixed initial stress in the South (as in Czech) and free stress in the North. (c) Carpathian Ukrainian dialects which have fixed penultimate stress in the western dialects, similar to neighboring Polish and Slovak dialects, and free stress in the east, transitioning to Ukrainian (Baerman 1999, ch. I, sec. 4). He finds that the tendency towards fixed stress has two motivating factors: (1) prosodic, and (2) morphological, which interact with one another. For our purposes, it suffices to focus on his overriding phonological principle, the Basic Accentuation Principle (BAP), which states that (already in Common Slavic) "Stress the leftmost accented vowel or, in the absence of accented vowels, the leftmost vowel." Of the case studies he examines, he finds that only in initial fixed-stress languages does the BAP apply phonologically as a default, that is, to southern Kashubian (Baerman 1999, Ch. I, sec. 2.1; Ch. V., sec. 1). The analysis can be extended to much of the Czech and Slovak speech territory, save for the transitional Czech-Polish dialect zone in Silesia and the Carpathian dialects transitioning between Slovak and Ukrainian. The Czech-Polish phenomenon, whereby penultimate stress prevails in some localities, may be assumed to be a function of relatively recent contact.Baerman did not take into account the SW Czech phenomenon.

In the following we shall extend Baerman's areal approach by taking into account the larger Slavic dialect context of the phenomenon under investigation in SW Czech. Following Holub's analysis, we can observe that the profile of the D-type (and perhaps to a lesser extent, P-type) contains both elements of canonical fixed initial stress (common to Czech, Slovak, S Kashubian, and Upper Sorbian), but also has at least superficial resemblance to pitch-accent systems found elsewhere in Slavic, notably in the South Slavic Slovene and BCS areas, albeit without the phonemic contrast typical in the areas that have continued to preserve 
pitch-accent. Nevertheless, as we shall note, pitch-accent characteristics persist also in South Slavic systems that have lost pitch as a distinctive feature.

Slovene dialect patterns have preserved pitch-accent systems in such a way that at least one of the reconstructed rising stresses (most likely the "old acute" rising contour) is preserved (merging with the other source of rising pitch) and contrasts with the inherited falling tone (Greenberg 2000, 2003, 2007, 2008). In BCS, save for the innovative neo-štokavian type, pitch-accent has been preserved through a contrast of the "neo-acute" rising tone and the inherited falling tone. Here, the inherited "old acute" has been replaced by short-falling stress, which Greenberg has explained elsewhere as a result of the differential realization of glottalization (resulting in depressed/rising pitch) vs. a glottal stop; falling pitch with short stress (Greenberg 2007). The result is that, insofar as the pitch-accent contours differ (in addition to the distribution of them), the Slovene type has a relatively low pitch in the stressed syllable and the post-tonic syllable has a higher pitch. In BCS, the rising tone is characterized by a rise in the pitch movement in the stressed syllable and an equal high tone in the following syllable. The situation is sketched schematically in Figure 9:

Figure 9. Pitch-accent profiles in Slovene, BCS (* marks place of stress)

Slovene (standard, Upper Carniolan)

$\begin{array}{llll}\text { kráva } & \text { L*L.H } & \text { 'cow' } & \text { "old acute" } \\ \text { dúša } & \text { L*L.H } & \text { 'soul' } & \text { "neo-acute" } \\ \text { gláva } & \text { L*L.H } & \text { 'head' nom. sg. } & \text { retraction from final stress } \\ \text { glâvo } & \text { H*L.L } & \text { 'head' acc. sg. } & \text { "circumflex" }\end{array}$

BCS (generalized Čakavian, Kajkavian, Posavian Štokavian)

$\begin{array}{lll}\text { kräva } & \mathrm{H}^{*} \text {.L } & \text { "old acute" } \\ \text { dúša } & \mathrm{L} \text { H.H } & \text { "neo-acute" } \\ \text { gláva } & \mathrm{L} \text { H.H } & \text { retraction from final stress } \\ \text { glâvu } & \text { H*L.L } & \text { "circumflex" }\end{array}$

Apart from these, we can observe unusual types, which we shall sketch in somewhat more detail. In Zilja Carinthian (Slovene, NW Carinthia, Austria) the pitch movement of the pitch-accent system is realized over the entire word. Thus, following Pronk's schematization and data from Neweklowsky's instrumental study, we find the following possibilities as in Figure 10:

Figure 10. Pitch-accent in Zilja Carinthian (Neweklowsky 1973: 218ff; Pronk 2009: 18-19)

$\begin{array}{lll}\text { stári } & \mathrm{L} * \mathrm{~L} . \mathrm{H} & \text { 'old' masc. nom. pl. } \\ \text { stâri } & \mathrm{H} \text { H.L } & \text { 'old' def. masc. nom. sg. } \\ \text { méso } & \mathrm{L} * \mathrm{H} & \text { 'meat' } \\ \text { réémo } & \mathrm{L} * \mathrm{~L} . \mathrm{H} & \text { 'we say' } \\ \text { prèkwadi } & \mathrm{L} * \mathrm{~L} . \mathrm{H} & \text { 'purlins' } \\ \text { žègnanega } & \text { L*.L.H.H 'of something blessed' }\end{array}$


$-\quad$ More pertinent to the issue at hand, however, is the loss of pitch distinctions. In a study by Lundberg and Priestly tone loss in the village of Selena Rožu (central Carinthian dialect, Austria). Here, tone loss proceeds through generations and progresses hierarchically, first in short-vowel syllables, next in monosyllables, and finally in posyllabic words. There are several issues of note:

- As in Zilja, pitch is diffused over the length of the word.

- Short-stressed syllables, which occur most frequently in final position, loses pitch contrasts most readily. This is reminiscent of Baerman's observation that all of the mobile-stress-losing dialects he observed had as a commonality a ban on final stress (Baerman 1999: 131).

- Conservative systems (1-4) preserve relative height of the tonic and posttonic syllable.

- Pitch-losing systems (informants 5, 7) have lost relative height in long-rising post-tonic syllables (the rising tone is manifested as high in the tonic and post-tonic syllable).

- In contexts where pitch is lost, it is phonetically slightly rising $(21,23)$.

Figure 11: Tone loss in Sele na Rožu (Lundberg and Priestly 2009: 24)
Informant ( $1-6$ oldest $\rightarrow$ youngest $)$
Realization
$1,2,3$
CVCV: Relative Height of Tonic \& Post Tonic
CVC: Distinctive Contour
Short: No Tonemic Oppositions
4
CVCV: Same as 1, 2, 3
CVC: No Tonemic Oppositions
Short: No Tonemic Oppositions
5,7
CVCV: LR - Both High, LF - Same as 1, 2, 3, 4
CVC: No Tonemic Oppositions
Short: No Tonemic Oppositions
6
No Tonemic Oppositions

In another area of Slovene, the eastern region of Haloze (Pannonian dialect), Lundberg has noticed a type of pitch loss that has resulted in neutralization of pitch, yielding a stress and quantity system that is unusual with regard to other Slovene systems in that the neutralization has resolved in favor of rising pitch. Moreover, he notes that the pitch contour is similar to the rising pitch in neighboring Kajkavian dialects with pitch-accent systems (Lundberg 2001).

As Greenberg has demonstrated in (2007), the pitch contour of the rising stress in Slovene and Croatian dialects are indicative of the Proto-Slavic origins of the rising stress.

The relevant points are these:

- Old acute developed primarily on the basis of the loss of laryngeals, which developed into a glottal stop (following the theory in Kortlandt 1975). 
- Glottal stops may subsequently be either preserved, lost, or yield glottalization (creaky voice, distributed throughout the syllable) in the syllables containing them.

- Where glottal stops are preserved as such, they universally yield short falling stress (the BCS and eastern Slovene kräva type). This parallels the Baltic situation, where glottal stops yield falling pitch.

Where glottal stops yield glottalization (creaky voice), this phonation type depresses the fundamental frequency in the accented syllable, leading to a low tone, followed by a post-tonic high tone. Moreover, glottalized or creaky-voiced phonated vowels are universally realized as relatively long. This is the pattern in the western and central (standard) Slovene kráva type (Kavitskaya 2002: 79; Greenberg 2007: 83-84).

- Rising tone from other sources (neo-acute) patterns differently: it is a rising tone realized in the tonic and post-tonic syllable. This is the Čakavian, Kajkavian dúša type.

- Western and central Slovene generalized the old acute type kráva, such that dúša follows (has merged with) the same pitch contour.

- Eastern Slovene and Western BCS (Čakavian, Kajkavian, Posavian Štokavian) have generalized the dúśa type, but could not have merged it selectively with the kräva type in pitch-accent systems, since it never yielded a rising pitch.

- Eastern Slovene, however, was free to generalize the rising pitch contour in systems that lost pitch oppositions altogether.

The facts adduced above allow us to sketch the following working hypothesis. As was pointed out, we have no direct evidence for the transition between pitch-accent and fixed-stress + quantity systems, so we are limited to circumstantial evidence. Given the facts sketched above, we can reconstruct the following scenario:

- In Bohemian dialects, as in Slovene, old-acute stress yielded glottalization in stressed syllables, which correlates with length and depressed pitch contour in the syllable.

- Pitch contour was generally lost in most areas of Czecho-Slovak, but retained longer in SWC.

- As functional load of pitch-accent decreased and fixed stress prevailed, the pitch-contour of the depressed/rising tone was generalized as a phonetic (non-contrastive) phenomenon, which co-occurs with vowel length (see Czech dialect maps, above).

In this way we have been able to enrich Baerman's analysis of the transition between Common Slavic pitch-accent to fixed stress by explaining an anomalous system in SW Bohemia. The matter is illuminating, because it shows a parallel, if not a direct connection to, the developments in Slovene dialects to which the area would naturally have been connected before language shift to German/Hungarian sundered the continuum between $\mathrm{W}$ and S Slavic.) 
This hypothesis leaves some open questions. The first of these is a function of the analysis of data: we have still not analyzed enough data to be certain of what is statistically typical of the PD pitch phenomenon. The second is a question of the historical interpretation. Above we have operated on the assumption that the SWC phenomenon is a relic of a more widespread phenomenon ("glottalization") in Bohemian. It is also possible that the founder population of the SWC dialects was of a different type than the rest of Bohemia. We hope to address these questions in subsequent studies.

\section{References}

Baerman 1999 = Matthew Baerman, The Evolution of Fixed Stress in Slavic, München: Lincom Europa, 1999 (LINCOM studies in Slavic linguistics 15).

Balhar - Jančák 2006 = Jan Balhar - Pavel Jančák, Český jazykový atlas 5, Prague: Academia - Ústav pro jazyk český AV ČR, 2006.

Bělič 1972 = Jaromír Bělič, Nástin české dialektologie, Prague: Státni pedagogické nakladatelství, 1972.

Greenberg 2000 = Marc L. Greenberg, A Historical Phonology of the Slovene Language: Historical Phonology of the Slavic Languages, Heidelberg: Universitätsverlag C. Winter, 2000 (Historical Phonology of the Slavic Languages 13).

Greenberg 2003 = Marc L. Greenberg, "Word Prosody in Slovene from a Typological Perspective," Sprachtypologie und Universalienforschung (STUF) no. 56 (3), 2003, 234-251.

Greenberg 2007 = Marc L. Greenberg, "Phonetic Evidence for the Development of the 'Acute' Tone in Slavic," in Tones and Theories: Proceedings from the International Workshop on Balto-Slavic Accentuation, edited by Mate Kapović - Ranko Matasović, Zagreb: Institut za hrvatski jezik i jezikoslovlje 2007, 95-108.

Greenberg 2008 = Marc L. Greenberg, A Short Reference Grammar of Slovene, München: Lincom Europa, 2008 (LINCOM studies in Slavic linguistics 30).

Greenberg 2010 = Marc L. Greenberg, "Nova opisna slovnica ziljščine," Slavistična revija 58 (4) (2010): 489-494.

Havránek 1934 = Bohuslav Havránek, "Nářečí česká," in Jazyk, edited by Oldřich Hujer, Prague: Sfinx, 1934, 84-218.

Holub 2011a = Zbyněk Holub, "K problematice současného úzu paroxytonického př́zvuku v mluvě západních a jižních Čech,” Slavia Centralis 4 (2) (2011), 5-31.

Holub 2011 b = Zbyněk Holub, "K problematice specifických prozodických poměrů v některých lokalitách západních a jižních Čech," in Viator Pilsnensis, neboli, Plzeňský poutník: literárnímu vědci Viktoru Viktorovi k sedmdesátinám, Plzeň: Západočeská univerzita, 2011, 248-260.

Holub 2011c = Zbyněk Holub, "Напряжение на предпоследнем слоге слова в южно- и западночешских говорах," in Русское слово: сборник научных 
трудов к юбилею декана филологического факультета Волгоградского государственного сочиально-педагогического университета Р. И. Кудрямовой 3, edited by Е. И. Алешенко - Е. В. Брысина - В. И. Супрун, Волгоград: Волгоградский государственный социально- педагогический университет, Филологический факультет, Кафедра общего и славянорусского языкознания, 2011, 19-22.

Kavitskaya 2002 = Darya Kavitskaya, Compensatory Lengthening: Phonetics, Phonology, Diachrony, New York - London: Routledge, 2002 (Outstanding Dissertations in Linguistics).

Kortlandt 1975 = Frederik Kortlandt, Slavic Accentuation, Lisse: Peter de Ridder Press, 1975.

Lundberg 2001 = Grant H. Lundberg, "Typology of Tone Loss in Haloze, Slovenia: an Acoustic and Autosegmental Analysis," Slovenski jezik / Slovene Linguistic Studies no. 3 (2001),169-189.

Lundberg - Priestly $2009=$ Grant H. Lundberg - Tom Priestly, "Pitch Opposition in Sele: Slovene Tone Loss in Austrian Carinthia," Slovenski jezik / Slovene Linguistic Studies no. 7 (2009), 3-28.

Neweklowsky 1973 = Gerhard Neweklowsky, Slowenische Akzentstudien, Vienna: Verlag der Österreichischen Akademie der Wissenschaften, 1973 (Schriften der Balkankommission, Linguistische Abteilung).

Petřík 1936a = Stanislav Petřík, "O plzeňském ,zpívání"," Naše řeč no. 20 (8) (1936), 196-201.

Petřík 1936b = Stanislav Petřík, "O plzeňském ,zpívání‘: Domažlice," Naše řeč no. 20 (9) (1936), 221-223.

Pronk 2009 = Tijmen Pronk, The Slovene Dialect of Egg and Potschach in the Gailtal, Austria, Amsterdam - New York: Rodopi, 2009 (Studies in Slavic and General Linguistics 36).

Voráč 1955 = Jaroslav Voráč, Česká nářeči jihozápadní: studie jazykově zeměpisná 1-2, Prague: Československá akademie věd, 1955 (Česká nářečí 2).

\section{Obpanonska prozodijska vzporednica na besedni ravni: paroksitoneza $v$ jugozahodnem češkem narečju}

\section{Povzetek}

V slavistiki velja češko-slovaški besednoprozodijski tip za konfiguracijo s stalnim naglasom na prvem besednem zlogu in možnost kolikostnega nasprotja $\mathrm{v}$ katerem koli zlogu besede. Znana izjema je šlezijsko narečje, kjer prevladuje poljska zvrst s stalnim naglasom na predzadnjem zlogu (»paroksitonija «) brez kolikostnih nasprotij. Manj znana je naglasna podoba $v$ dveh arealih $v$ jugozahodnem češkem narečju (1: Plzen, 2: Doudleby pri Čeških Budjejovicah), kjer prevladuje "paroksitonija« ob stalnem naglasu na prvem zlogu in možno kolikostno nasprotje v naglašenih in nenaglašenih zlogih, ki se na prvi pogled zdi podobna šlezijski konfiguraciji. $\mathrm{Na}$ 
$\hookrightarrow \quad$ osnovi nedavnih terenskih raziskav v jugozahodnem češkem narečju, ki jih je izve-

[T] del Zbyněk Holub, imamo o pojavu nove, natančnejše podatke. Čeprav se naglasna N podoba jugozahodnega češkega narečja delno in na prvi pogled ujema s šlezijskim - $\quad$ tipom, se $v$ jugozahodni češčini ob kolikostnem nasprotju pojavlja tudi posebni tonत ski potek pri »naglasu« na predzadnjem zlogu. Namesto da bi povezali jugozahodno - naglasno podobo s šlezijskim tipom, jo lahko upravičeno povežemo s konfiguracijo as $\mathrm{v}$ ziljskem slovenskem narečju, vzporedne razvoje pa opažamo tudi drugod v sloE- venskih narečjih, kar se uvršča v celostno sliko razvoja naglasnih tipov v slovanskih - jezikih. Možni potek razvoja $v$ jugozahodni češčini in slovenščini se razčlenjuje $v$ $<$ drugi polovici prispevka. 